\title{
SOCIAL RESPONSIBIIITY CODE - INSTRUMENT FOR BETTER CORRELATION OF POLICIES IN THE FIELD OF BIO-ECONOMY
}

Please cite this article as:

Dinu, V., 2019. Social Responsibility Code - Instrument for Better Correlation of Policies in the Field of Bio-Economy. Amfiteatru Economic, 21(52), pp. 499-501.

DOI: $10.24818 / \mathrm{EA} / 2019 / 52 / 499$

The contemporary society focuses on issues such as sustainability, environmental protection, sustainable consumption, promotion of clean technologies, sustainable agriculture, biodiversity conservation, food security, fair employment, fair trade, green biotechnology, expanded use of renewable energy etc. Due to the wide scope and different incentives, sustainable development raises major social, economic and environmental challenges, mainly for companies. At the same time, there is a more acute need for analyzing the stability and prospects of any company, not only in terms of financial indicators, but also in terms of social and environmental performance. In this respect, the enactment of the EU Directive 34/2013 (amended by 95/2014), requiring large companies to disclose nonfinancial information and information on diversity, is significant. Responding to the social interest, even enterprises that are not subject of the Directive compete in disclosing their social responsibility through policies, measures and actions. While, for most organizations, social responsibility has, by definition, a voluntary nature, and the existing regulations are vague, companies tend to publish results that show them in a favorable light and silently pass the negative impact - in some respects - of their work. In order to mitigate the heterogeneity of approaches and to facilitate comparisons, identify best practices, develop rankings and track progress, several codes, "reference frameworks" have been initiated for the integration of social responsibility policies and for reporting achievements on these issues. Among these, United Nations Global Compact, the Global Reporting Initiative, Accountability Framework and ISO 26000 are better known internationally.

Amid a certain consensus on the usefulness of publishing non-financial information on social responsibility and sustainability, there is a need to expand and deepen research on the impact of corporate reporting systems on economy and business. Thus, it is of particular interest to study the extent to which the transparency of firms' policies and results on social responsibility issues contributes to accelerating the conversion of the economy to more sustainable forms of production, such as those labeled as bio-economy. Bio-economy includes the production of renewable biological resources as well as the conversion of these resources and waste streams into value-added products such as food, feed, bio-products or bioenergy and involves new approaches that come from research, innovation and scientific leadership to bring about concrete improvements in the social, economic and environmental well-being.

Starting from these premises, the current issue of the journal brings to the fore papers that contribute to a better understanding of how social responsibility codes are used by companies that operate in the field of bio-economy, as well as of the effects of such codes on companies, the economy and the society.

Resulting from an applied research, the paper Social Responsibility, an Essential Strategic Option for a Sustainable Development in the Field of Bio-Economy identifies and analyzes the implementation level of fundamental principles and values of corporate social responsibility, strategic priorities and methods used by significant Romanian organisations

Vol. $21 \cdot$ No. $52 \cdot$ August 2019 
from three relevant sub-fields of bio-economy: the industry that processes bio-resources, organic food industry and organic farming. The paper also develops a hierarchy of strategic (economic, social and environmental) interests of top managers from the analysed organizations, reflecting the new business philosophy.

The study Social Responsibility of Firms and the Impact of Bio-Economy in the Intelligent Use of Renewable Energy Sources brings to the fore several issues regarding renewable energy sources that are not used at maximum potential in Romania, reasons for their nonuse, opportunities and solutions that can be adopted for the exploitation of these types of renewable energy sources. The authors show that an important role in this undertaking is played by companies who, by adopting a social responsibility code, can not only generate benefits, but also create a positive image, with favorable consequences for all parties involved.

The paper Congruency Effects of Corporate Responsibility Code Implementation on Corporate Sustainability in Bio-Economy aims to identify the main congruency forces that can constitute both the strategic and the operational dimension related to the implementation of a social responsibility code within companies from the bio-economy sector, and can add to the increase of corporate sustainability. The analysis shows that the congruency effect is stronger when companies show a greater tendency towards social reporting and pay more attention to relationships with stakeholders. Moreover, the authors emphasize that the results of the study can provide a useful support to managers of bioeconomy firms, in order to implement a social responsibility code, that would enhance the congruency effect of the operational and strategic dimensions and accelerate the transition to more sustainable business forms.

The research Manifestations of the European Ecological Footprint from the Perspective of Social Responsibility Codes analyses the ecological footprint of production in European countries, considering how it can be supported by applying social and environmental responsibility codes, given the sustainability of economic development, as a promoter of bio-economy. The paper focuses on following issues: the analysis of the development of the ecological footprint of production in European countries, as well as of the impact on corporate responsibility; modelling the ecological footprint behaviour, depending on social and educational factors, the sustainability of development (the use of renewable energy), and the economy opennes; the multicriteria hierarchy and clustering of the European countries, based on selected variables, the predicted behavior of the ecological footprint of production, as a prerequisite for optimizing social responsibility for the environment and applying social responsibility codes in business.

The study on Effects of Integrated Reporting on Corporate Disclosure Practices Regarding the Capitals and Performance starts from the idea that embedding integrated thinking in corporate management and reporting practices should generate improved performance, whereas the latter can be, in its turn, a main incentive for a wide scale implementation of integrated reporting. The paper tests this idea, considering the diversity of the reported indicators and the development of the performance, by analyzing reports of 49 European companies included in the International Integrated Reporting Council's Pilot Program for two moments in time: 2013 and 2016. The authors aim to identify how and to what extent integrated thinking translated into reporting practices and performance, during the implementation of the International Integrated Reporting Framework.

The next two papers approach companies listed on Bucharest Stock Exchange and focus on the way in which enterprises that perform operations are affected by the trend towards bioeconomy, i.e.: the paper Encompassing Non-Financial Reporting in a Coercive Framework for Enhancing Social Responsibility: Romanian Listed Companies' Case investigates how 
Romanian energy companies (Oil \& Gas and Utilities) disclose in their reports issues regarding the environment, social responsibility and governance, prior to and after the implementation of the European Directive 2014/95 (EUD) in order to explore the effects of the new regulation entered into force in January 2017. The paper An Empirical Analysis of Corporate Social Responsibility Effects on Financial Performance for Romanian Listed Companies examines the interaction between social performance, as defined by CSR, and the corporate economic and financial performance. The authors point to practical consequences related to the companies' tendency to implement measures that are associated with bio-economy, with a reduced environmental impact, and the tendency to perform social programs and activities.

The novelty of the paper Financial Communication in the Context of Growth of Social Responsibility of Companies is given by the approach of financial communication in the context of the growing corporate social responsibility and the increasing access of the European audience to the Internet. The authors propose a transversal study that connects the fields of financial communication, bio-economy and corporate governance. In this line, the authors studied to what extent the concerns of corporations to increase the corporate governance index, along with the high level of $R \& D$ expenditures produce concrete effects on Biodiesel production, recycling and waste, as essential components of bio-economy.

The paper Bioeconomy and Social Responsibility in the Sustainable Hotel Industry refers to bio-economy strategies and practices implemented by hotels in Romania, emphasizes the possible theoretical and practical implications in the hospitality industry from Romania, and provides managers with support for future directions of action in implementing specific bio-economy strategies. The paper explores strategies and practices of bio-economy implemented by hotels in Romania, given the growing awareness of sustainable development and socially responsible practices

The article Role of Tour Operators and Travel Agencies in Promoting Sustainable Tourism investigates the behavior of three major tour operators in Romania in relation to the requirements of internationally recognized standards for sustainable tourism. The authors note that the issue of social responsibility is recognized and consistently reflected in the strategies, programs, actions and concrete measures. However, the firms concerned have not implemented a standardized code and the specific procedural system for the tour operator industry, nor do they envisage this in the near future, as they do not feel pressure from the demand side and are still uncertain about cost-benefit ratio of such an investment. The authors appreciate that, under these conditions, the potential of tour operators to boost the shift to sustainable tourism throughout the supply chain of tourism remains largely untapped. To better exploit the potential of tourism to support sustainable economic development and, implicitly, progress towards bioeconomy, it is necessary to better align public policies with the interests of the business environment and to involve more actively other actors, especially education institutions.

It is estimated that further harmonization of reporting standards on social responsibility, without altering the voluntary nature of measures and actions taken by firms, can stimulate commitment and efforts to achieve transparency and accountability.

Editor in Chief, Vasile Dinu 